\title{
COVID-19 Vaccines Can Initiate or Exacerbate A Rheumatic Disease; A Report of 4 Cases
}

\author{
COVID-19 Aşıları Romatizmal Hastalı̆̆ Tetikleyebilir veya Alevlendirebilir; 4 Vakalık Derleme
}

\section{Resit Yildirim, Dondu Uskudar Cansu, Mustafa Dinler, Cengiz Korkmaz}

Division of Rheumatology, Department of Internal Medicine, Eskişehir Osmangazi University, Eskisehir, Turkey
Correspondence:

Resit YILDIRIM

Division of Rheumatology,

Department of Internal Medicine,

Eskişehir Osmangazi University,

Eskisehir, Turkey

e-mail: celeng18@gmail.com

\section{Abstract}

Vaccination has been playing an anchor role in controlling the COVID-19 pandemic. Notably, mRNA-based novel vaccines against SARS-CoV2 have increased some speculations among rheumatologists and patients with autoimmune disorders, whether they may reactivate the presenting disease or unveil a new autoimmune disease because of the absence of randomized controlled tirals pioneering their effects in this specific population. Despite these theoretical concerns on immune hyperactivation, vaccination has been performed widespreadly because benefits outweigh mortality risks in this population. Recent observational studies showed that disease flares are seen in rheumatic diseases after vaccination. On the other hand, case reports and case series have been increasingly published that autoimmune disorders may be emerged following vaccination. Herein, we report 4 cases including flares and an occurence of rheumatic disease after mRNA vaccination.

Keywords: COVID-19, mRNA vaccines, immune hyperactivation, autoimmune disorders

\section{Özet}

Aşılama, COVİD-19 pandemisinin kontrol altına alınmasında önemli bir köşe taşı rolü oynamıştır. Özellikle SARS-CoV2'ye karşı geliștirilen mRNA bazlı yeni aşılar, romatizmal hastalığı olan populasyonda yeterli randomize kontrollü çalıșmaları olmaması sebebiyle, hem romatologlar hem de otoimmun hastalığı olanlarda hastalığın alevlenmesi, ya da ek bir otoimmun hastalığın ortaya çıkması hususunda endişelere yol açmıştır. Teorik olarak immun hiperaktivasyona yol açabileceği düşünülse de pandeminin bu hasta grubundaki riski göz önüne alınarak așılama uygulamalarına devam edilmiștir. Literatürde romatizmal hastalığı olanlarda aşı sonrası aktivasyon olduğuna dair gözlemsel veriler mevcuttur. Öte yandan aşı ilişkili olduğu düşünülen yeni tanı otoimmun hastalıklar olgu bildirileri şeklinde yayınlanmaktadır. Burada romatoloji kliniğimizde mRNA aşısı sonrası ortaya çıkan ve alevlenme ile bașvuran 4 hasta sunduk.

Anahtar Kelimeler: COVID-19, mRNA aşıları, immun hiperaktivasyon, otoimmun hastalıklar 


\section{Introduction}

While Covid-19 vaccines are widely used in the world to create protection to Covid-19 infection and to overcome the increased overload on the healthcare systems, our knowledge on acute and chronic effects of vaccines on the immune system is not yet very sufficient. As a result, there are some concerns with the vaccine side effects. This concern is especially greater for patients with autoimmune diseases. Theoretically, the emergence of an autoimmune disease or exacerbation of an existing disease are among these possibilities (1). Herein, with the report of these four cases, we intend to increase the attention of the community that novel mRNAbased vaccines may affect the immune system via different pathways, which in turn leading to variable clinical rheumatic flares or disease occurrence.

\section{Case 1}

A 55-year-old male with a previous diagnosis of hypertension and psoriasis, developed granulomatosis with polyangiitis (GPA) two weeks following the first dose of BNT162b2 (BioNTech-Pfizer) vaccine implementation. The patient was admitted with new-onset progressive dyspnea and hemoptysis. Laboratory findings revealed decreased hemoglobin $(\mathrm{Hb})(8.5 \mathrm{~g} / \mathrm{dl})$, elevated white blood cell (WBC) count (17000), serum creatinine $(1.24 \mathrm{mg} / \mathrm{dl}$ : reference range 0.5 $0.9)$, C-reactive protein (CRP) $(224 \mathrm{mg} / \mathrm{l}$; reference range $0-5 \mathrm{mg} / \mathrm{dl}$ ), and sedimentation rate (ESR) $(97 \mathrm{~mm} /$ hour). Urine evaluation demonstrated hematuria with dysmorphic erythrocytes but no proteinuria. CT scan of the chest demonstrated bilateral multifocal ground-glass opacities, suggesting pulmonary hemorrhage. The polymerase chain reaction (PCR) test for SARS-CoV2 was negative. Serum cytoplasmic anti-neutrophilic antibody (c-ANCA) was highly positive $(++++)$ with increased anti-proteinase (PR) 3 levels ( $>100$; reference range 4.9-5). Renal biopsy demonstrated pauci-immune crescentic glomerulonephritis. Based on clinical, radiologic, histopathologic, and serologic findings, diagnosis of GPA possibly due to vaccination was considered. The patient was commenced on the combination of plasmapheresis, pulse methylprednisolone, and cyclophosphamide. He was discharged on day 15 of the hospital stay after resolving pulmonary symptoms and normalization of hemoglobin levels. He is currently on $8 \mathrm{mg}$ of methylprednisolone completed the third cycle of cyclophosphamide recently.

\section{Case 2}

A 77-year-old with seropositive rheumatoid arthritis (RA) diagnosis, who has been in remission on leflunomide (disease activity score (DAS)-28 in the last visit was 2) since 2018, presented by bilateral joint pain in wrists. The symptom developed within three weeks of the second dose of BNT162b2 (BioNTech-Pfizer) vaccine administration. Physical examination was remarkable for bilateral wrist arthritis. SARS-CoV2 PCR test was negative. Serum levels of CRP (171 $\mathrm{mg} / \mathrm{dl}$; reference range $0-5 \mathrm{mg} / \mathrm{dl}$ ) and ESR ( $84 \mathrm{~mm} /$ hour; reference range $0-20 \mathrm{~mm} /$ hour) were elevated with calculated DAS28 of 6 . After the symptomatic relief and decline in inflammatory markers with the administration of a moderate dose of methylprednisolone (32 $\mathrm{mg}$ /day), the patient was discharged with certolizumab pegol. DAS28 was calculated at 2.3 at the last visit.

\section{Case 3}

A 54-year-old female with longstanding adultonset Still's disease (AOSD) under control with a weekly anakinra (IL-1 antagonist) regimen for the last one year hospitalized due to the development of fever, rash on the chest and upper extremities with elevation in serum inflammatory markers (ferritin to $1811 \mathrm{ng} / \mathrm{ml}$, CRP to $74.6 \mathrm{mg} / \mathrm{l}$, ESR to $45 \mathrm{~mm} /$ hour). At last admission, serum ferritin level was 101 $\mathrm{mg} / \mathrm{dl}$ (reference range) with normal CRP and ESR levels. No evidence of infectious foci was identified. The past medical record revealed that 15 days before this admission, she was instituted the second dose of BNT162b2 (BioNTech-Pfizer) vaccine. She was discharged with anakinra on daily basis and $32 \mathrm{mg}$ of methylprednisolone after clinical and serologic improvement. 


\section{Case 4}

A 55-year-old male was admitted to our center with a two-day history of excruciating pain, redness, and warmth in the left first metatarsophalangeal joint three weeks following the second dose of BNT162b2 (BioNTech-Pfizer) vaccine. Pat medical record showed 10 years of gout diagnosis using allopurinol and colchicine on-demand only during gout attacks, which the last one was reported 2 years ago. The last recorded uric acid level was found $5.9 \mathrm{mg} / \mathrm{dl}$. Physical examination was consistent with' Podagra'. Laboratory investigations showed elevated CRP $(21.7 \mathrm{mg} / \mathrm{l})$, uric acid $(7.2 \mathrm{mg} / \mathrm{dl})$, ESR (12 mm/hour). Diagnosis of vaccine-induced gout attack was considered, and colchicine commenced after that. On day 10, the colchicine dose was decreased with the resolution of the attack.

\section{Discussion}

Although the exacerbation of preexisting rheumatic diseases or the onset of new illness following vaccination in these 4 cases may be coincidental, the short duration between the vaccination and disease onset or flare and the elevated incidence of these kinds of events in clinical practice support a possible relationship (1-6). These observations are indeed based on temporal association between vaccine administration and disease presentation. Thus, these data should be criticized attentively, especially in terms of vaccine-induced emergence of an autoimmune disease. A recent prospective observational study, which evaluated the disease flare and reaction of rheumatic patients following SARS-CoV2 mRNA vaccine administration, revealed that the required treatment of disease flares was only in $11 \%$ of participants. In this study, $91 \%$ of participants experienced exacerbations in the previous rheumatic symptoms, and $72 \%$ of patients reported a newly developed symptom. These vaccinerelated events were reported more frequently, particularly after the second dose. No severe flares requiring hospitalizations were established by the authors (7). However, the lack of baseline disease activity before initiating the vaccine and the type of data gathered that was based on patient reports seem to be significant limitations of this study. According to the results recently published by COVID19 Global Rheumatology Alliance Vaccine Survey, flares were found in $13.4 \%$ of participants, among whom $4.6 \%$ of those required a change or increased dose of medication in the treatment (8). Of note, the clinicians should keep in mind that temporary holding of anti-rheumatic agents during vaccination due to efficacy concerns might also play as a confounding role. Therefore, these results need to be assessed attentively before making a precise conclusion.

Based on recent studies, a novel terminology, "trained immunity", has been identified that the innate immune system cells have its own memory features that produce an augmented response when subjected to secondary stimulation (9). Consistent with the literature, we observed that the underlying rheumatic disease exacerbated or a new disease emerged as a result of immunologic rebound, usually after the second dose of vaccine. These clinical observations might be conceivable findings that support the partial role of "trained immunity" in vaccine-related immunologic rebounds. For mRNA-based vaccines, immune activation might appear via different pathways. mRNA itself, as an immunogen, can stimulate inflammasomes following entry via endosomal Toll-like receptors, which then causes increased production of type 1 interferon, resulting in activation of the innate immune system. On the other hand, the lipid nanoparticle (LNP) carrier, the vital component for the protection of mRNA, can serve the mRNA as an antigen to $T$ cells to activate the adaptive immune system (10). The another important part of this report is that mRNA vaccination may have the potential to trigger attacks of autoinflammatory disorders, which we observed it in gout. Despite these fundamental mechanisms of action identified for the novel vaccines, it could not be ignored that further investigations are needed to enlighten the yet unexplained vaccine-related adverse events encountered in clinical practice. In this new era, these clinical observations undoubtedly will give rise to deep exploration for novel pathogenic mechanisms, and subsequently pioneering new treatment options. 


\section{REFERENCES}

1. Terracina KA, Tan FK. A flare of rheumatoid arthritis after COVID-19 vaccination. Lancet Rheumatol 2021; 7: e469-70.

2. Magliulo D, Narayan S, Ue F, Boulougoura A, Badlissi F. Adult-onset Still's disease after mRNA COVID-19 vaccine. Lancet Rheumatol. 2021 ;3:e680-e682.

3. Obeid M, Fenwick C, Pantaleo G. Reactivation of IgA vasculitis after COVID-19 vaccination. Lancet Rheumatol. 2021;3:e617.

4. AlGhoozi DA, AlKhayyat HM. A child with Henoch-Schonlein purpura secondary to a COVID-19 infection. BMJ Case Rep 2021; 14: e239910.

5. Kreuter A, Licciardi-Fernandez MJ, Burmann SN, et al. Induction, and exacerbation of subacute cutaneous lupus erythematosus following messenger-RNA or adenoviral-vector based SARS-CoV-2 vaccination. Clin Exp Dermatol 2021 Jul 22.

6. Shakoor MT, Birkenbach MP, Lynch M. ANCAAssociated Vasculitis Following Pfizer-BioNTech COVID-19 Vaccine. Am J Kidney Dis. 2021 ;78:611-13

7. Connolly CM, Ruddy JA, Boyarsky BJ, Barbur I, Werbel WA, Geetha D, Garonzik-Wang JM, Segev DL, Christopher-Stine L, Paik JJ. Disease Flare and Reactogenicity in Patients With Rheumatic and Musculoskeletal Diseases Following Two-Dose SARS-CoV-2 Messenger RNA Vaccination. Arthritis Rheumatol. 2022 ;74:28-32.

8. Sattui SE, Liew JW, Kennedy K, et al. Early experience of COVID-19 vaccination in adults with systemic rheumatic diseases: results from the COVID-19 Global Rheumatology Alliance Vaccine Survey. RMD Open 2021; 7: 001814.

9. Arts RJW, Moorlag SJCFM, Novakovic B, et al. BCG Vaccination Protects against Experimental Viral Infection in Humans through the Induction of Cytokines Associated with Trained Immunity. Cell Host Microbe 2018; 23: 89-100.

10. Teijaro JR, Farber DL. COVID-19 vaccines: modes of immune activation and future challenges. Nat Rev Immunol 2021; 21: 195-97. 